\title{
If biological diversity has a price, who sets it and who should benefit?
}

\begin{abstract}
Washington. A one-year-old agreement between Merck \& Co., Inc. and a group of Costa Rican scientists coupling economic development with the preservation of biodiversity in Costa Ricca (see Nature 353, $290 ; 1991$ ) has raised the question of who owns a nation's biological wealth. The agreement, which gives the world's largest pharmaceutical company the right to search for new medicines among the plants, insects and microorganisms collected from
\end{abstract} Costa Rica's protected forests, is seen either as a novel way to finance biodiversity or as an unconscionable sellout of the country's environmental heritage.

The arrangement has inspired a US legislator to propose an international aid programme to help nonprofit organizations within Latin America and the Caribbean to obtain the necessary scientific knowledge and commercial sophistication to enter into agreements such as that between Merck and the Instituto Nacional de Biodiversidad de Costa Rica (INBio). At the same time, the Costa Rican legislature is expected to vote soon on a bill that would provide increased public scrutiny and a larger share of the proceeds from such arrangements. The legislation has been revised to meet the concerns of drug companies planning to emulate Merck as well as the private research organizations that would receive royalties from the sale of any products developed from indigenous samples.

Much of the opposition to the agreement, led by the Museo Nacional de Costa Rica and a host of nongovernmental environmental organizations within Costa Rica, stems from INBio's private status. Critics are concerned about the confidential nature of such agreements, the lack of public accountability and the failure of such agreements to protect the rights of various social president of the Costa Rican environmental group, AMBIO, argues that although it is called a 'national' biodiversity institute, "INBio has no right and no authority to represent Costa Rica".

Carazo would like to see a larger role for the public in such agreements and a different distribution of the proceeds. Under the terms of the agreement, Merck has agreed to pay INBio \$1 million over two years in return for the opportunity to screen thousands of plant, insect and soil samples for new molecules with biological activity. INBio will any products developed from these groups within Costa Rica. Mario Carazo, receive 5 per cent royalties on the sale of

samples. Costa Rica's Ministry of Natural Resources, Energy and Mines will receive $\$ 100,000$ of the $\$ 1$ million paid to INBio by Merck and 50 per cent of any royalties monies that are earmarked for the conservation of biodiversity within Costa Rica. INBio intends to sign similar agreements with two European pharmaceutical companies before the end of the year.

The agreement between Merck and INBio

\section{IMAGE UNAVAILABLE FOR COPYRIGHT REASONS}

NATURE · VOL 359 • 15 OCTOBER 1992 protected areas.
The bill would weaken INBio's almost exclusive control over commercializing the country's wealth of biodiversity and distributing its benefits. Opponents have removed language that would have prevented companies from patenting inventions arising from the evaluation of Costa Rica's biodiversity. The bill, which covers flora and fauna but does not extend to microorganisms, must be voted upon before the end of December.

The Merck-InBio agreement, praised by such organizations as the World Resources Institute, the US National Academy of Sciences and the Royal Society in Britain, has become a model for the world because it was the first well-publicized deal to involve a developing nation and a multinational company. But critics argue that what may work in Costa Rica, which has a stable democratic government and where one-quarter of the land area has been set aside for the purposes of conservation, may not work so well in other Latin American countries. "INBio can be one model", says Elaine Elisabetsky, a pharmacologist at the Federal University of Rio Grande do Sul in southern Brazil, "but it shouldn't be the model".

Shortly before the US Congress adjourned last week, US Representative Robert Torricelli (Democrat, New Jersey) introduced a bill to set up a Western Hemisphere Biodiversity Cooperation Program within the US Agency for International Development. The programme would help nonprofit organizations within Latin America and the Caribbean to set up biological inventories and databases for purposes of conservation, science or commerce. Entitled the Economic Leadership through Environmental Cooperation Act, the bill is designed to encourage investment, principally by US pharmaceutical companies, in programmes to conserve biodiversity in Latin America.

Torricelli believes that grants of not more than $\$ 100,000$ to nonprofit organizations would give them the necessary institutional capacity to negotiate with and enter into bilateral agreements with institutions in the United States. One of the reasons that INBio was such an attractive partner to Merck was because it knew how to process samples and had already conducted an inventory of its enormous biological wealth.

Congress took no action on the bill, but Torricelli says that he hopes to reintroduce it in January with the support of a newly elected Democratic administration more receptive to the issue.

Diane Gershon 